\title{
DISASTER RISK ON REVIEW SCALE AND SPATIAL PLANNING ARCHIPELAGO REGION: THE RISK BASED ISLAND CLUSTER IN MOLUCCAS PROVINCE
}

\author{
Ferad Puturuhu ${ }^{\mathrm{a}}$, Restia Christianty \\ a Pusat Penelitian Bencana, Universitas Pattimura, Negeri Rumahtuga, Ambon, 97234, Indonesia
}

\section{ARTICLE INFO}

\section{Article history:}

Received: 6 January 2020

Accepted: 25 June 2020

Available Online: 11 July 2020

\section{Keywords:}

Disaster; Island Cluster; Risk; Scale of Review; Spatial

\section{Corresponding author:}

Ferad Puturuhu

Pusat Penelitian Bencana, Universitas

Pattimura, Ambon, Indonesia

Email: feradputuruhu@gmail.com

\begin{abstract}
Disaster risk reduction (DRR) by taking into account the spatial planning in its implementation is not easy, for the Moluccas which has the characteristics of the region that has many cluster islands, and the accessibility are still low. Thus it requires special handling in the island-based disaster risk reduction, which will certainly be different from disaster risk reduction efforts that were undertaken in the continental region. The purpose of this research is to design the spatial area of the island cluster in Moluccas Province based on disaster risk. The method used is literature through spatial analysis of island risk-based groups. Based on the results of disaster risk assessment by the BPBD of Moluccas Province, it has been obtained that there are islands based on disaster risk (RB-islands cluster). The high disaster risk level was the island cluster on RB III and IX, the medium disaster risk level was the island cluster on RB I, IV, VI, and VIII, the low disaster risk level was the island cluster on RB II, V, and VII. The RB island cluster is a model for reaching areas with high disaster risk, can easily identify what causes it. It become an input to mitigate it through the spatial arrangements for achieving a sustainable archipelago development. The regional spatial arrangements aimed at reducing disaster risk in the RB-islands cluster in the Moluccas through spatial planning, structural handling/civil engineering, education, and community empowerment.
\end{abstract}

Copyright (C) 2020 JGEOSREV-UNG This open-access article is distributed under a Creative Commons Attribution (CC-BY) 4.0 International license

\section{Introduction}

Disaster risk assessment is an approach to show the potential negative impacts that might arise due to an existing potential disaster. The potential negative impacts are also calculated by considering the level of vulnerability and capacity of the region. This potential negative impact illustrates the potential number of lives, property losses, and environmental damage exposed to potential disasters (BNPB, 2016). Disaster risk is a combination of danger/threat (hazard), vulnerability and capacity in a region. Disaster risk is also influenced by time and space, in addition to dynamic pressures that will affect some risky assets or sectors.

A disaster risk assessment in this case vulnerability and threat can be carried out by integrating the climate variables that will significantly affect the management of existing risks; both in the form of preventive action, mitigation and preparedness. Similarly, in the process of disaster reconstruction with the principle of "build back better" (Clinton, 2006). In the development context, integration of disaster risk reduction (DRR) and climate change adaptation leads to the incorporation of climate change (adaptation and mitigation) disaster risk into development programs that have been, are, or will be done (Lestari et al., 2018).

The United Nations (UN) (2018) in the Hospita (2019), through a report published by the UN Center for Disaster Epidemiology Research (CRED), states that throughout 2018 there were 281 natural disasters have occurred in the world. No part of the world has been spared the effects of extreme 
weather events that have had the effect of floods, droughts, storms and forest fires. The effects of extreme weather affected the lives of 57.3 million people. According to CRED, India, Philippines and China are the most affected countries of natural disasters, while Indonesia, India, and Guatemala are the countries with the most casualties.

As many as 3.4 million people worldwide are affected by the earthquake, tsunami and volcanic activity. While 4,321 of them died in an earthquake during the past year. In addition, flooding affected 35.4 million people last year, including 23 million people in Kerala, India. Floods in various parts of the world, especially in India, Japan, Nigeria and North Korea claimed 2,859 lives. While the storm affected 12.8 million people last year and caused 1,593 deaths. Europe and North America experienced a forest fire. The deadliest forest fires in 2018 were recorded in Greece (126) and in the US (88). CRED data reveal that 9.3 million people are affected by drought worldwide and the most occured in Kenya, Afghanistan, and Central American (Hospita, 2019).

In Indonesia, the most disasters from 2019 to early 2020 were typoon (puting beliung) with 575 events, followed by 390 floods and 356 landslides (DIBI-BNPB, 2017). Three regencies / cities with the highest disaster risk index scores in Indonesia are Southwest Moluccas, Moluccas Province (score 223.20), Majene, West Sulawesi Province (score 216.10), and Gunung Sitoli City, North Sumatra Province (score 215.6) (BNPB, 2018).

The Moluccas is an archipelago cluster which is one region with other territory separated by the sea which is divided into several clusters of big and small islands. The condition of topography in Moluccas Province is generally hilly along the coastline to the plateau. The characteristic of this region is influenced by the meeting of three tectonics plates include Australia, Pacific, and the Eurasian plate. The existence of this also makes the Moluccas into areas prone to disaster events.

The Law of the Republic of Indonesia Number 24 of 2007 on Disaster Management, followed by Government Regulation No. 21/2008 on Disaster Management Implementation, and Presidential Regulation No. 8/2008 on the National Agency for Disaster Management (BNPB) have indicated to implement efforts DRR in Indonesia. Disaster risk reduction aims to reduce the threat of physical, social, and economic vulnerability of disasters to minimum level of disaster risks. Knowledge and willingness are not sufficient to reduce disaster risk, the real action of everyone in disaster risk reduction is needed.In the context of overseeing the implementation of disaster risk reduction, the Moluccas disaster management plan (RPB) is applied for a period of 4 years. Each district/city already has a disaster management regional regulation.

The current disaster paradigm is more progressive understanding that disaster as part of development and disaster is a matter that does not stop. Therefore, disaster management can not be separated from development problems. Hence the effort is to integrate development program with disaster management (Husein, 2014). This paradigm considers that disaster management efforts are more directed to the identification of disaster-prone areas, identifying patterns that generate vulnerability and carry out structural mitigation activities such as building construction (houses, buildings, dams, embankments, etc.) as well as non-structural arrangements such as spatial planning including land, building standards, etc. (Godschalk et al., 1999; Bakornas PB, 2007).

Disaster risk reduction by taking into account the spatial layout in its implementation is not easy for the Moluccas with the islands and its characteristics. The accessibility factor is also still low. It requires special handling in the island-based disaster risk reduction, which would be different from disaster risk reduction efforts conducted in the continental region, such as Java, Sumatera, Kalimantan, Sulawesi, and others. It also needs the right method to save a lot of people and the region's infrastructure into sustainable development islands. The purpose of this study is to obtain a regional spatial model that can be run on a disaster risk-based island cluster $(\mathrm{RB})$.

\section{Method}

This research is a library research with improvement through the characteristics of each island cluster. The analysis used is the spatial analysis of island cluster in Moluccas based on disaster risk. The disaster risk map used is the result of a mapping conducted by the Moluccas Province Regional Disaster Management Agency (BPBD) as outlined in the disaster management plan document.

The discussion on this topic used various secondary data including: Moluccas Province disaster management plan (RPB), Moluccas Island cluster concept, Moluccas Province regional spatial plan (RTRW). Based on the disaster risk map with the characteristics of the existing area of island cluster, 
and the regional spatial plan. An analysis is carried out to produce a mitigation effort and better structured territorial space for each island cluster.

\section{Results and Discussion}

\subsection{Disaster risk in the Moluccas's Island cluster}

Moluccas is dubbed as the country of the 1000 Islands in Indonesia as a consequence of a very large number of islands. There are 1,422 islands consist of 970 already have name and 452 islands have not got the name (DKCS, 2016). Considering the geographical location of the large numbers islands, and the effectiveness in economic, health, infrastructure and poverty reduction in the Moluccas, the island cluster system of the eleven municipal districts of Moluccas were formed into the twelve-island clusters.

To illustrate disaster risk in Moluccas according to the result of risk assessment by the Moluccas Province Regional Disaster Management Agency in RPB 2012-2016 (BPBD, 2011), then used only 9 island clusters. The Southwest Moluccas was previously divided into two and Central Moluccas, and divided into three for disaster risk assessment which put together into the cluster. This integration is based on disaster risk reduction management which must be handled by each district in Moluccas.

Disasters will occur and have a disastrous impact if the scale of the threat is too high, the vulnerability is too great, and the capacity and readiness possessed by the community or government are not sufficient enough to overcome it. Threats or dangers will not be disastrous if the event does not incur a physical or mental loss. The value of disaster risk depends on the magnitude of threats and vulnerabilities that interact. The disaster risk assessment forms the basis for selecting strategies that are

Table 1. Example of the vulnerability and risk in the moluccas's islands cluster based on disaster risk in Moluccas Province

\begin{tabular}{|c|c|c|}
\hline No & Vulnerability & Risk \\
\hline 1 & The scarcity of clean water in Dobo & Community deals with the water crises \\
\hline 2 & Temperature is increased and extreme heat & $\begin{array}{l}\text { a) Drought in some areas of the Aru Islands, } \\
\text { MBD and some other places in the } \\
\text { Moluccas } \\
\text { b) In the sea can cause the "coral bleaching", } \\
\text { in Banda, Tual and some places that cause } \\
\text { death, decreased reproduction and coral } \\
\text { productivity }\end{array}$ \\
\hline 3 & $\begin{array}{l}\text { Infrastructure roads were cut off by the } \\
\text { natural disaster }\end{array}$ & $\begin{array}{l}\text { Community accessibility was cut off into the } \\
\text { district city, affecting the economic condition of } \\
\text { the community. An example in Huamual } \\
\text { behind SBB, Wamar Dobo Island, Ambon } \\
\text { Island, Central of Moluccas, etc. }\end{array}$ \\
\hline 4 & Uncertainty season & $\begin{array}{l}\text { a) Fishermen are difficult to get fish; it is } \\
\text { difficult to estimate the existence of fish, the } \\
\text { income of fishermen decreases } \\
\text { b) Planting calendars were changed, low of the } \\
\text { agricultural yields }\end{array}$ \\
\hline 5 & $\begin{array}{l}\text { Tidal waves that always hit coastal areas: } \\
\text { Southwest of Moluccas (MBD, Aru } \\
\text { Islands, West-Southeast of Moluccas } \\
\text { (MTB), and the Moluccas in general. }\end{array}$ & $\begin{array}{l}\text { a) Abrasion } \\
\text { b) Damaged-house in the coastal area } \\
\text { c) The Community's condition with a single } \\
\text { livelihood/income, such as } \\
\text { fisherman/woman, when the waves are } \\
\text { coming, the community has no income }\end{array}$ \\
\hline 6 & $\begin{array}{l}\text { Community stays to consume rice as the } \\
\text { staple food, not local foods }\end{array}$ & $\begin{array}{l}\text { a) The dependence on rice even though the } \\
\text { price increases } \\
\text { b) Loss of the Moluccas land plasma nutfah }\end{array}$ \\
\hline 7 & $\begin{array}{l}\text { Dense settlements on the slopes } \\
\text { hills/mountains }\end{array}$ & $\begin{array}{l}\text { Vulnerable to landslides and floods, such as in } \\
\text { Ambon City }\end{array}$ \\
\hline
\end{tabular}


considered capable of reducing disaster risk for the needs of spatial planning (BNPB, 2018)

According to the multi-disaster risk assessment, The Moluccas has a medium to high-risk level. According to the types of disasters, the low-risk levels include earthquakes, landslides, and whirlwinds; moderate risk levels include droughts, floods, epidemics, and social conflicts; and high-risk level disaster are tsunami, volcano, abrasion, tidal wave, and forest and land fire (BPBD, 2016). The disaster that has a high risk, highly characterized by the characteristics of the archipelago with a group of small islands and bounded by the vast sea that is the threat (USAID APIK, 2018).

Based on the Table 1, disaster risk-based island cluster (RB-islands cluster) illustrates that the island clusters with high risk levels are RB III and IX, the medium disaster risk is the island clusters of RB I, IV, VI , and VIII, the low disaster risk level is an island clusters of RB II, V, and VII. The high risk of RB III and IX because in both clusters of this island has 9 types of disaster threats with medium to high risk, and has a physical, social, economic, and environmental vulnerability that greatly affects the region and its people do not have the ability in the face of danger. In the social context of vulnerability as a result of exposure, adaptability (adaptive capability) and sensitivity (sensitivity). The weaknesses exist in the midst of communities and environments that support the high risk of disaster in a region. While the existing capacity of the RB-islands cluster is strongly influenced by the factors that stick with the small island communities. The problem are poverty, social culture and education (Kusumastanto, 2006 in Triyono 2015).

In relation to the Figure 1, there are several characteristics of the community in the archipelago includes an open culture, source of community life depends on natural resources, economic activity is strongly influenced by the weather and season, especially with the occurrence of global climate change and the role of the market is crucial in the development of community activities (Triyono, 2015). These characteristics do exist in the nine island cluster in Moluccas Province and are shared by the community.

This characteristic will be vulnerable if it is affected by the environmental conditions that have been damaged and have disaster threats, such as coral reef, mangrove, seagrass, pollution, and sea (tsunami, abrasion, tidal waves). These environmental conditions are causing the capacity of the community and the environment has decreased, and mitigation efforts will not work. The following are examples of the causes of vulnerability that have an impact on disaster risk in some clusters in the Moluccas's (Table 1).

\subsection{Spatial planning for a sustainable development based on a disaster risk reduction}

Spatial planning is important in a safe-space utilization plan from the impact of natural disasters. In spatial arrangement, there are criteria of disaster prone location, distribution of critical area location, and disaster risk area. Spatial planning can minimize the impact of disaster because the premise of spatial arrangement is the balance of the environment or in other words the utilization of a region for various activities must consider the carrying capacity of the environment (Tondobala, 2011; Imran. 2013).

The realization of spatial planning is the same as disaster mitigation and climate change adaptation or as a tool for disaster mitigation and climate change adaptation. In the context of identification of disaster prone areas, this is an effort to support spatial planning by providing information relating to the vulnerability of the region to disaster. Hence, disaster risk can be observed and anticipated in the pattern of space. In other words, disaster risk knowledge of a region is useful to determine the structure and spatial pattern of the region.

\subsection{Legal foundation for spatial planning based on a disaster mitigation}

Some legal foundations in Indonesia and the results of agreements of several countries around the world that serve as the basis for the implementation of spatial planning based on disaster mitigation for sustainable development are as follows.

1. Law of The Republic of Indonesia number 24 of 2007 concerning Disaster Management

The Articles explains the importance of spatial planning and disaster management to support development are:

a. Article 9 , the authority of regional governments in the implementation of disaster management include:

- Decision on disaster management policy in line with regional development policy;

- Development planning that include elements of disaster management policy;

b. Article 32 , paragraph 1 point a, states that in the disaster management, the government may determine disaster-prone areas shall come under prohibition areas for settlements

c. Article 35, states that the disaster management without disaster as referred to in Article 34; item 


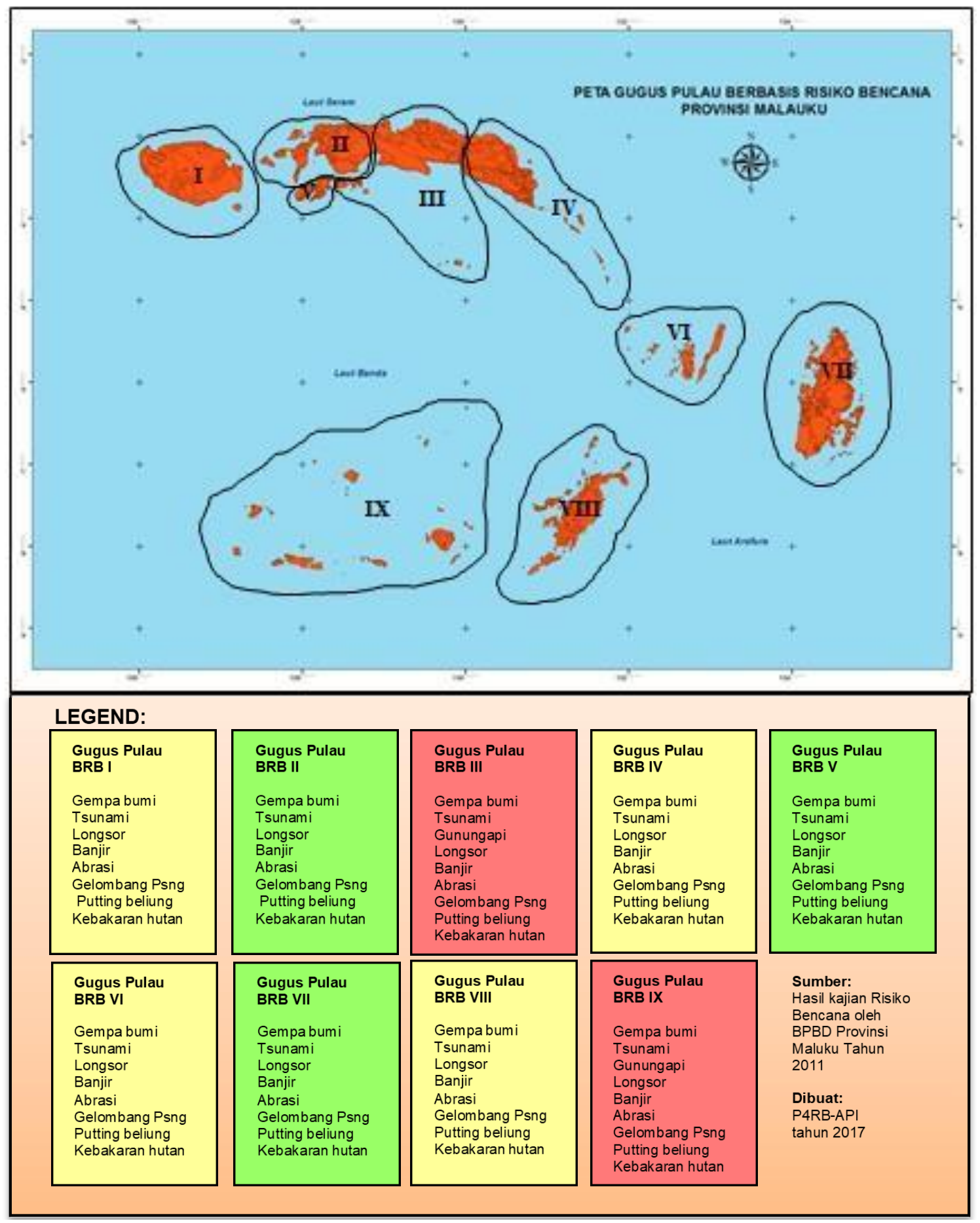

Figure 1. The island cluster map based on disaster risk in Moluccas Province

d) integration into development planning and item f) spatial structure plan implementation and enforcement;

d. Article 42, in paragraph 1) Implementation and enforcement of the spatial planning as referred to in Article 35 Sub-Article f, shall aim to reduce disaster risk including the application of regulations on spatial structure, safety standards and the imposition of sanctions on violators, carry out monitoring and evaluation of the spatial implementation and achievement of safety standards.

2. Law of The Republic of Indonesia number 27 of 2007concerning the management of coastal zone and small islands

Article 31 with the following paragraphs are explained as follows:

a. Local Government determines the boundary of the coastal setback which is based on the topographic, biophysical, coastal hydro-oceanography characteristics, economic and cultural needs, and other provisions. 
b. Determination of the boundary of the coastal setback is in conformity with the provisions on:

- The protection against earthquake and / or tsunami;

- The protection of the coast against erosion or abrasion;

- The protection of coastal artificial resources from storms, floods, and other natural disasters;

- The protection of coastal ecosystems such as wetlands, mangroves, coral reefs, seagrass beds, sand dunes, estuaries, and deltas;

- The regulation of public access, and

- The regulation for canal and waste.

c. Further provisions on the coastal setback as referred to in paragraph 2 shall be regulated by the Presidential Regulation.

3. Government Regulation No. 64 of 2010 on Disaster Mitigation in Coastal Zone and Small Islands.

4. This government regulation was made by considering Law No. 27 of 2007 on the management of coastal zone and small Islands. What is meant by disaster mitigation in accordance with Chapter I, Article 1 point 4 is an effort to reduce disaster risk, either structurally or physically through physical development of natural and/or artificial or non-structural or nonphysical through the enhancement of the ability to face disaster threat in coastal zone and small Islands. This government regulation also caontains another chapter or article that explains the strategy in disaster mitigation efforts on small islands in order to support sustainable development that prospers the people.

5. Moluccas Legal Documents in the: regional spatial plan 2007-2027 (BAPPEDA, 2007)

6. The Moluccas Province's regional spatial plan in Chapter 4 describes the "disaster risk management direction in the utilization of the space of Moluccas Province". There is 3 disaster risk management in the utilization of space that needs to be considered includes management of the spatial arrangement, management through an information system and engineering, and; management through education and community empowerment.

7. Hyogo Framework for Action (ISDR, 2005)

The paradigm shift is reflected in Law of The Republic of Indonesia number 24 of 2007 also influenced by the Hyogo Framework for Action (HFA) 2005-2015, which mandates 3 (three) strategic objectives are as follows:

a. Integration of disaster risk reduction on sustainable development policies, plans, and programs, prioritizing prevention, mitigation, preparedness and reducing vulnerability.

b. The development and strengthening of national and local institutional capacity, as well as the community, to jointly build resilience against disaster threats.

c. Inclusion of a disaster risk reduction approach to preparedness planning and implementation, emergency response and post-disaster recovery.

Since the implementation of the Hyogo Framework for Action in 2005-2015, documented in national and regional progress reports in its implementation and other global reports, the progression has been made in reducing disaster risks at local, national, regional and global levels with other countries and stakeholders, leading to a decline in mortality in cases of some catastrophic threats. Reducing disaster risk is a cost-effective investment in preventing future losses. Effective disaster risk management contributes to sustainable development.

8. The Sendai Framework for Disaster Risk Reduction 2015 - 2030 (UN, 2015)

The Sendai Framework is a derivative of the Hyogo Framework for Action (HFA) 2005 - 2015: Building the Resilience of States and Communities to Disaster. There are important points in Sendai's framework that explain the importance of disaster risk reduction and its efforts through the planning of city space records for sustainable development as follows.

a. In the importance of the principles in point $h$, clarifies that: the development, the strengthening, and implementation of the relevant policies, plans, practices, and mechanisms should lead to the coherence of a sustainable development and growth, food security, health and safety, climate change and variability, environmental management, and agenda disaster risk reduction. Disaster risk reduction is critical to achieving sustainable development.

b. In the description of the second action priority, on "strengthening disaster risk governance for disaster risk management at the national and local levels", point $\mathrm{d}$, explains that: to encourage the establishment of the necessary mechanisms and incentives to ensure compliance with legal requirements of the sectorial rules, including land use and urban planning, building codes of ethics, environmental and resource management and health and safety standards, and updating them as needed, to ensure adequate focus on disaster risk management. 


\subsection{Some appropriate spatial arrangements for the disaster risk-based island cluster (RB-islands cluster) in the Moluccas}

Spatial planning for $\mathrm{RB}$-island clusters in the Moluccas, its governance certainly refers to the various legal bases which have been previously described. Spatial management for disaster risk reduction associated with climate change adaptation for the island clusters with medium to high average multi bound risk are:

1. The Spatial Arrangement

a. Creating/generating thematic maps: disaster vulnerability, micro-zonation maps in the earthquake-prone areas, and creating the tsunami evacuation maps that are installed in tsunamiprone areas. All island clusters should have multi-hazard maps, except for volcano-prone maps devoted only to the cluster of RB III's Islands (Banda, Sarawerna (Teon), Lawarkarwa (Nila), Legatala (Sarua) and IX (Gunungapi Wetar, Wurlali (Damer)). The micro-zonation map should be made on all RB's island clusters, and the tsunami evacuation route map should be a priority for high tsunami risk areas in 6 RB's islands clusters (III, IV, VI, VII, VIII, IX).

b. Identifying safe locations, so it is hoped that this safe location will be a viable place to build settlements and other important facilities and become relocation areas for the disaster victims' settlements. This safe location should really fit the safe location criteria of various disasters.

c. Allocating the building placement (vital housing and public facilities such as hospitals, schools, police stations, firefighters, etc.) in areas that are safe from disaster. All RB's island clusters should make allocations of these important public facilities placement in safe areas.

d. It is necessary to have a building management plan set forth in the local regulations, which are insightful and consider the disaster aspects so that sustainable building principles can be achieved. For example earthquake-resistant buildings, suitable buildings and good positions to build in areas at risk of tsunamis, and floods (stage-house in the West Malacca Subdistrict, East Nusa Tenggara Province is shown in Figure 2a) or volcanic areas (teletubic houses like in Yogyakarta).

e. Preparing the disaster lane and evacuation place, especially for tsunami, volcano, and earthquake disaster. It is important for the community self-rescue action of the disaster considering the criteria for the safe location to which it is intended.

f. Providing the buffer zone to reduce tsunami wave energy so that its destructive power decreases. For example, 300 - 400 meters from the coast to the mainland is destined for
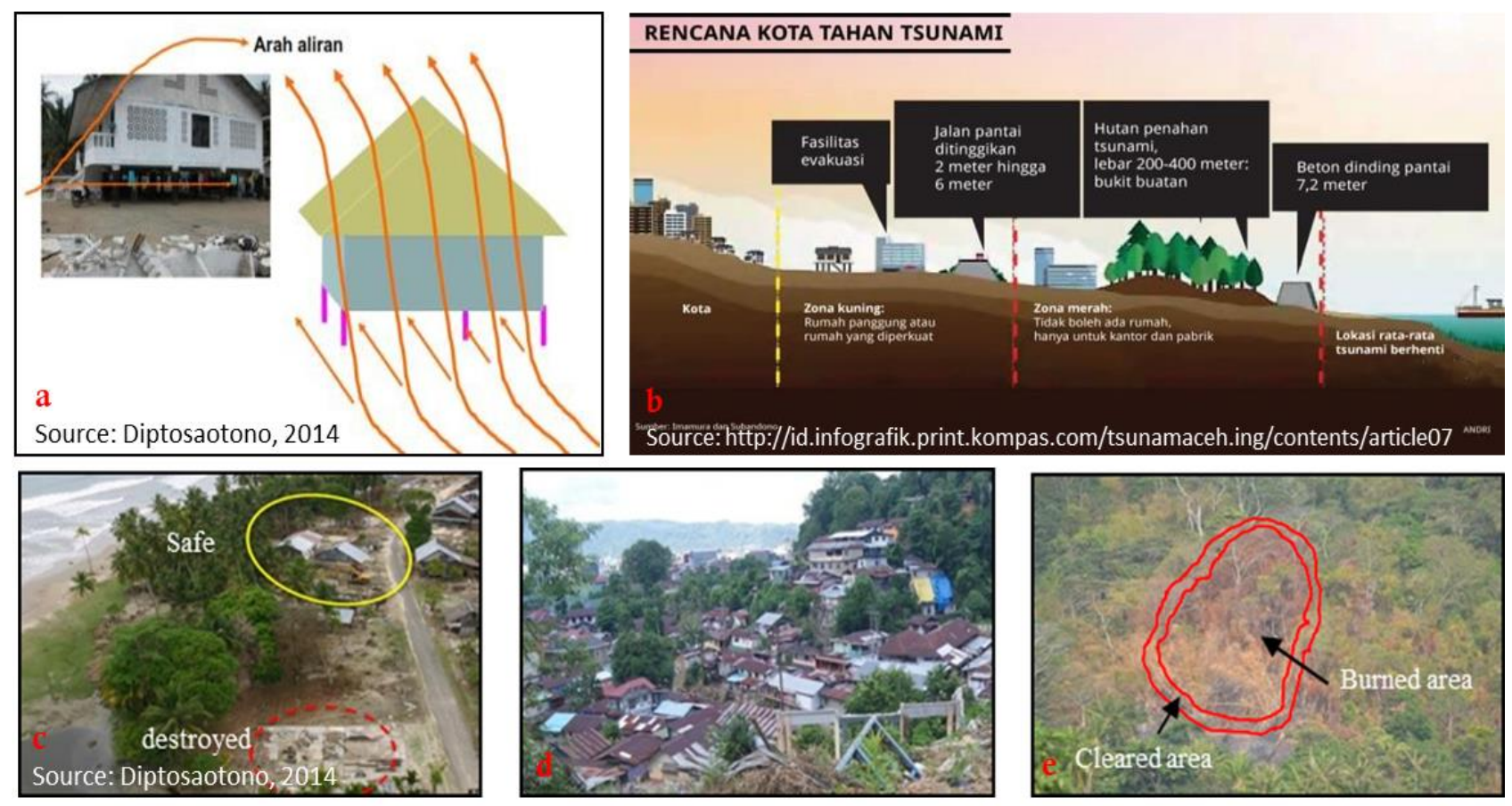

Figure 2. a) Stage house for tsunami and flood; b) Masterplan tsunami-resistant city; c) The Benefits of the greenbelt in facing the tsunami; d) The Settlements construction within the Slope $>15 \%$, that should be; e) The ways to burn land in Damer MBD 
mangroves/greenbelt, then 600 - 700 meters from the mangrove is more to the land again for the pond, then 600 meters from the pond for the fishing village, and only after that for a limited settlement area, more shown in Figure $2 b$. Greenbelt is very important as a coastal protector (Figure 2c). The 6 RB's island clusters with high tsunami risk should be arranged in such away. For the Island's group, RB IX is largely considered safe because it has a good greenbelt mangrove only on Wamar Island, where Dobo as the capital district's is located there and should be reorganized so as to have better coastal protection to prevent tsunami, abrasion or tidal impacts that may occur.

g. Directs development on stable soils and on slopes below 15\%. The landslide-prone areas are directed as green open spaces. Especially for the RB V's island cluster of Ambon City with high population density on the slopes with a percentage $>15 \%$ (Figure $2 \mathrm{~d}$ ), should be a particular concern in spatial planning. It should be also restrictions on land clearing activities for settlements in slope areas by running incentive programs. For people who do not build their houses on the slope areas will be given incentives from the government with a variety of reliefs in the existing arrangements in accordance with the provisions. The people who still wanted to build their houses in the slope areas, there are no reliefs of the government in their various arrangements or in accordance with the applied-provisions in each region.

h. The arrangement of vegetation for landslide

- Local vegetation, with deep-rooted nature, is lightly titled, its branches are easy to grow after being trimmed (e.g. lamtoro and pete) and restricting the paddy fields and ponds in landslideprone areas;

- Planting Dalbergia sp (such as sonokeling, sono siso), gliricidae and kaliandra on the cliff areas;

- Planting the swietenia macrophylla or swietenia microphylla (mahogany), albicia and bamboo on the slope area;

- Gully plug, with bamboo (bamboo apus) that is grown on erosion grooves, which is followed the contour with a distance of 0.3 meters $x 0.3$ meters.

i. Carrying out the reforestation and setting alluvial soil due to flooding. This program should be carried out on the island cluster of RB I, II, III, IV, and V with a high level of risk and severe flooding throughout the disaster in the Moluccas.

j. Using local wisdom for disaster mitigation and people's welfare. One example that should be developed in the Moluccas to minimize the forest fires is a land clearing model, undertaken by the communities in Damer, MBD (island cluster RB IX). The clearing of farmland is conducted by limiting the land and clearing the area of 2 - 3 meters its width from the existing grass or trees. The communities just burn the land to be cultivated. In this way, the land and the surrounding forest will not burn (Figure 2e).

2. Engineering/Information Systems

It is related to structural disaster mitigation, and facilities provided to deliver early warning of disaster events. The following are described the handling of structural / engineering for each disaster.

\section{Earthquake}

a. Developing the earthquake resistant-construction techniques, both for public facilities and houses (Figure 3). For example using buildings from wood and lightweight materials for the house because it is more secure than heavy buildings. It is recommended for areas that are often the epicenter of the earthquake and the area through which fault/fracture, such as some areas in Ambon City (RB V Islands group) and in the Central of Moluccas district (island cluster RB III).

b. Reviewing the perfection of important building facilities (hospitals, schools, firefighters, communication installations), to make them as the earthquake-resistant buildings. As implemented by UNESCO in 2016 that is to evaluate the construction of 100 earthquake resistant-schools in the Moluccas (Ambon City and Central of Moluccas) using a tested- system for Indonesia, where it is only held in Moluccas and Pangandaran.

c. Preparing the emergency communications systems i.e. Early Warning System (EWS)'s equipment in the form of sirens, and messages to the general public concerning their security through mass media such as radio and as much as possible ways through android gadgets with applications that are now widely available. 


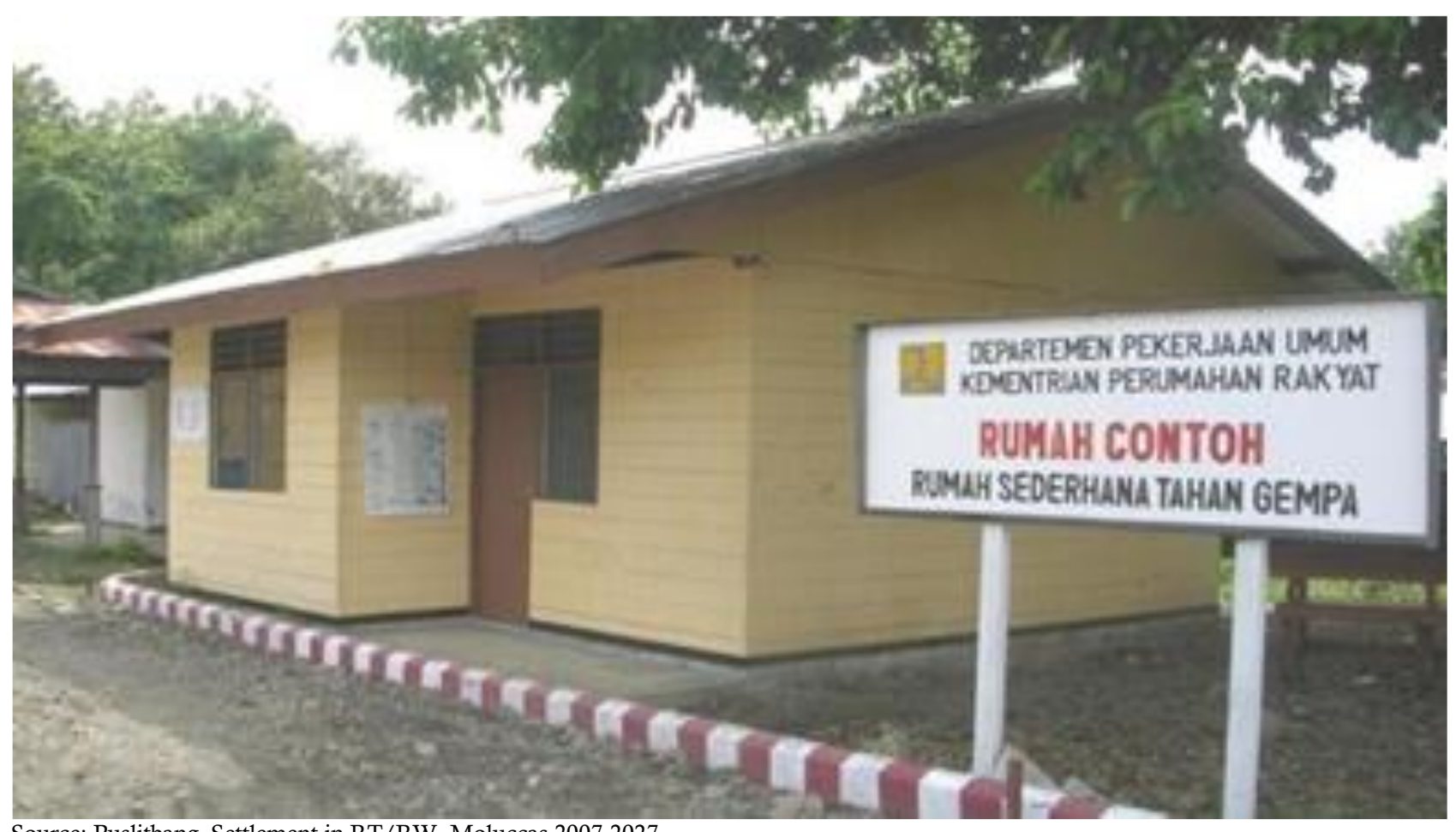

Source: Puslitbang-Settlement in RT/RW, Moluccas 2007-2027

Figure 3. An example of the resisting house form the earthquake

\section{Tsunami}

a. Equipping with early warning system (EWS). In the Moluccas, it is newly and only available in the island clusters of RB III (Banda Island) and RB V island (i.e. Ambon City). EWS in the form of siren shall be owned by each RB island cluster with having high tsunami risk at 6 RB's islands, in addition to RB I, III, and V island clusters.

b. Strengthening the buildings to withstand a strong wave and current. The foundation of the structure can be constructed to resist erosion and scour by the current. The ground floor is made open to allow seawater to pass, to reduce the scouring current on the foundation (as described in the figure).

c. In spatial arrangements, transport systems are constructed and modified to facilitate a rapid massevacuation;

d. Using the seawall structure, such as seawall, sea dikes, and breakwaters, river gates to hold or reduce tsunami pressure.

\section{Landslide}

a. Improving the soil drainage, such as soil nailing, hydro-seeding, and drainage system

b. Running the structural works, such as rock netting, shotcrete, block pitching, stone pitching, retaining wall, gabion wall, installation of geotextile. This installation of the geotextile model is temporarily used to overcome the landslide in the rear Huamual area of SBB regency (RB II island cluster), with coconut-husk base-material (Figure 4).

Flood

a. Complementing with some warning and detection/forecasting system of flooding. There are several options from the simple (involving the officers or volunteers' observation to observe the rainfall and river water boundaries) to sophisticated use of rainfall gauges and computerized the models. One example is ALERT (an automated local evaluation at the time of the flood event), in collaboration with the river basin.

b. Using the media as a medium to spread the flood's danger and warnings using radio, television, and sirens. Hence its disaster emergency (SOP) should be set for all of the RB island clusters.

c. Protection of vegetation from fires, deforestation, and overgrowing.

d. Relocating elements that clog the flooded roads, including the cleaning of sediments and debris from the river.

e. Flood deflection, including dikes and dams. However, dikes and dams tend to collapse and can be destroyed by the earthquakes so they must be carefully engineered to anticipate the maximum water 


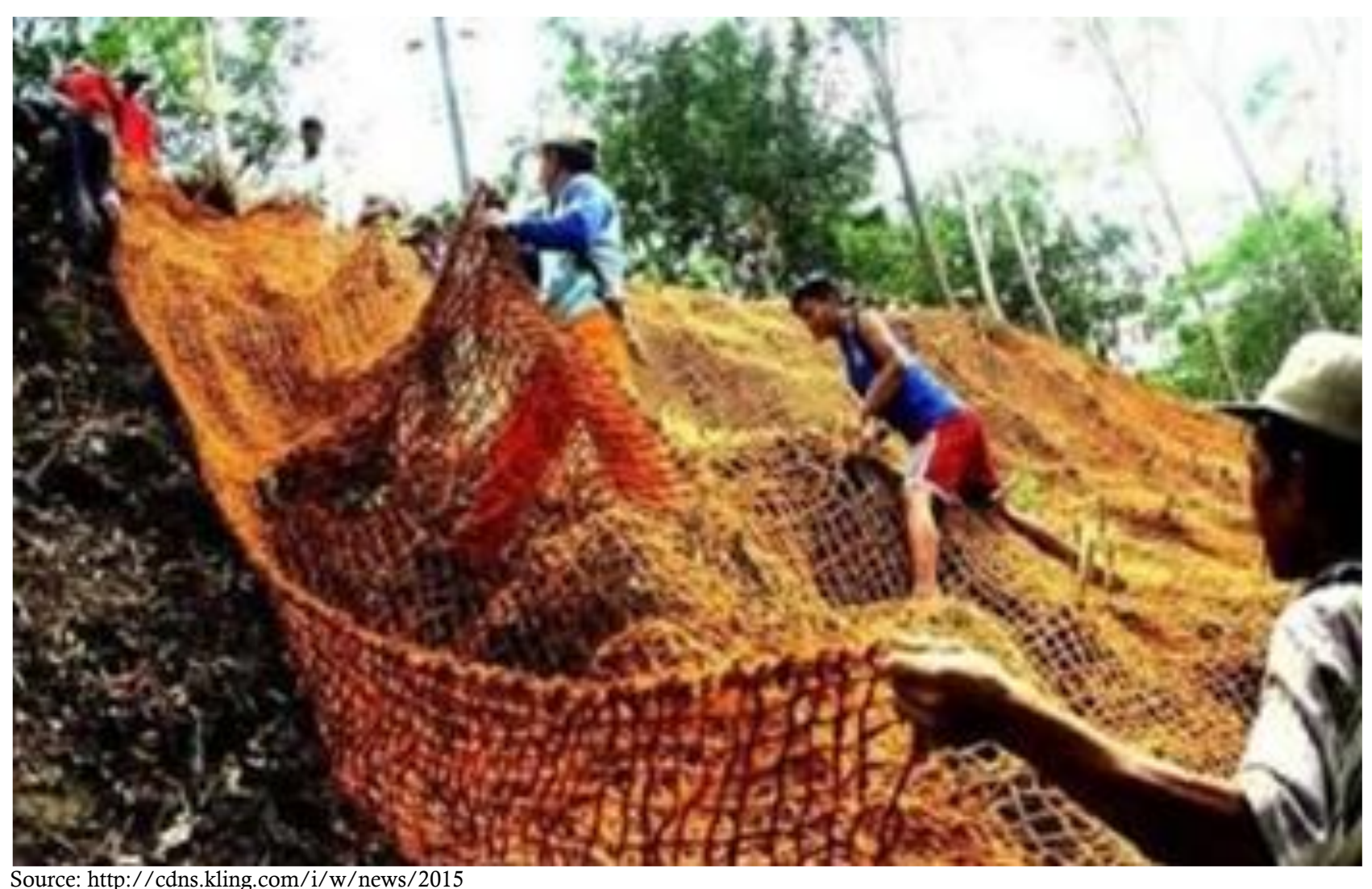

Figure 4. Installation of geotextile coconut-husk enables to preventing landslide

levels. One example is the Waiela watershed in the Central of Moluccas district (RB III), which should be a lesson for other RB's island clusters that are at high risk of flooding.

f. Using the flood-resistant building design, such as raising the floor/room above the possibility of flood boundary (house construction stage, as described island in the earlier figure). The building was withdrawn from the waters/rivers site. The land that is surrounding by the building should be protected from erosion. The riverbed is stabilized with stone or vegetation construction, especially near the bridge.

\section{Volcano}

a. Building a DAM is the way to resisting the volcano lava around the slopes, this way thus should be a concern for spatial planning around the volcano site in the RB III and IX, where most of which are located on the foot of the volcano's slopes and they still belong to dangerous zones.

b. Building a suggested house for the area around the volcano site in order to avoid the burden of volcanic ash deposits. The criteria of the house are the slope of the rooftop is $45^{\circ}$ or steeper, the rooftop is more often assisted by a pole, diagonal, it is recommended that the rooftop should be made of zinc to resist the heat from the pebble, and it should be also built a pillar at the center of the building, or a teletubic construction house (Home World, 2012).

The success of disaster risk reduction efforts for sustainable development, in addition to spatial planning, through spatial regulatory management and structural/ engineering mitigation as described above. It is equally important that the management of education and community empowerment in the Moluccas's RB- island cluster. Encouraging for better education, the disaster mitigation dissemination effort's measures that can be implemented with various methods, and the empowered communities as a community with the availability of potential resources can help to reduce disaster risks (UNESCO \& UNICEF, 2012).

Implementation of disaster risk reduction efforts on the RB's cluster in Moluccas Islands is also expected to be in line and can answer the sustainable development goals in Indonesia (BPS, 2016), which is the 11th goal of "making cities and settlements inclusive, safe, resilient, and sustainable ", with some achievement targets as follows (ITC, 2018):

1. By 2030, significantly reducing the number of deaths and the number of the affected people, and substantially reducing the relative of economic losses to the global disposal of gross (GDP) caused 
by disasters, focusing on protecting the poor and vulnerable people.

2. By 2020, substantially increasing the number of cities and settlements that adopt and implement an integrated policies and planning on inclusion, resource efficiency, mitigation and adaptation to climate change, resilience for disaster, and developing and implementing a holistic disaster risk management which acrosses all lines, according to "The Sendai Framework for disaster risk reduction 2015-2030 (UN, 2015).

\section{Conclusions}

The Moluccas as based on disaster risk level can be divided into nine disaster risk-based island cluster (RB-islands cluster). The RB's island cluster is a model for designing spatial planning based on disaster risk reduction (DRR) including climate change adaptation (API) in the Moluccas Islands region with different multi-bound risk levels. A spatial layout that can be run in the RB's island cluster is spatial planning which focuses on spatial management and structural (technical/information) mitigation, supported by education management and community empowerment. Hopefully, through the spatial arrangement of the nine RB's island clusters, sustainable development goals in the Moluccas will be achieved.

\section{Acknowledgments}

The author extends his gratitude to his friends at P4RB-API UNPATTI, who have supported authors with various data related to risk reduction and sustainable development for the archipelago, as well as for the organizing committee of the National Seminar on Themes: Sustainable Development for the Islands Region of Cooperation between Pattimura University and Padjadjaran University. It is hoped that the paper in this "concept" frame can be useful and become a reference for DRR practitioners, and development planners at national and regional levels.

\section{References}

[Bakornas PB] Badan Koordinasi Nasional Penanggulangan Bencana. (2007). Konsepsi Pengurangan Risiko Bencana. Bakornas PB.

[BAPPEDA] Badan Perencanaan Pembangunan Daerah. (2007). RTRW Maluku 2007-2027. Provinsi Maluku.

[BNPB] Badan Nasional Penanggulangan Bencana. (2018). Indeks Risiko bencana Indonesia (IRBI). Jakarta.

[BNPB] Badan Nasional Penanggulangan Bencana. (2016). Risiko Bencana Indonesia (RBI). Jakarta.

[BPBD] Badan Penanggulangan Bencana Daerah. (2016). Rencana Penanggulangan Bencana (RPB) 2016-2020. Badan Penanggulangan Bencana Daerah Provinsi Maluku.

[BPS] Badan Pusat Statistik. (2016). Tujuan Pembangunan Berkelanjutan (Sustainable Development Goals) di Indonesia. Badan Pusat Statistik/Statistics Indonesia.

Clinton, W. J. (2006). Key Propositions for Building Back Better. Office of the UN Secretary-Generals Special Envoy for Tsunami Recovery.

DIBI-BNPB. (2017). Data Bencana Alam di Indonesia 2019-2020. http://bnpb.cloud/dibi/tabel1a. akses 15 Februari 2020.

DKCS. (2016). Daftar Jumlah Pulau di Maluku. http://www.nomor.net. Akses 23 Februari 2017.

Godschalk, D. R., Beatley, T., Berke, P. R., Brower, D., \& Kaiser, E. J. (1999). Natural hazard mitigation: Recasting disaster policy and planning. Washington, D.C.: Island Press.

Hospita, M.E. (2019). Bencana alam sepanjang tahun 2018 renggut 10.000 nyawa Laporan PBB mengungkapkan bahwa India, Filipina, dan China adalah negara yang paling terdampak bencana alam. Zehra Ulucak. https://www.aa.com.tr/ Dalam Maria Elisa Hospita | 30.01.2019.

Husein, R. (2014). Bencana di Indonesia dan Pergeseran Paradigma Penanggulangan Bencana: Catatan Ringkasan. Universitas Muhamadiah Yogyakarta (UMY).

Imran, S.Y. (2013). Fungsi Tata Ruang dalam Menjaga Kelestarian Lingkungan Hidup Kota Gorontalo. Jurnal Dinamika Hukum. 13 (3). 457-467.

[ISDR] International Strategy for Disaster Reduction. (2005). Hyogo Framework of Action (HFA) 2005-2015: Building the Resilience of Nations and Communities to Disasters. World Conference on Disaster Reduction. 18-22 January 2005, Kobe, Hyogo, Japan.

[ITC] International Training Centre. (2018). Tujuan Pembangunan Berkelanjutan. 
Lesatari, T.A., Eko B.P., Didik F., Kuswantoro, Aswin R., Salira V. (2018). Kajian Risiko Bencana Pesisir. Wetlands International, Partners for Resilience.

Peraturan Pemerintah Republik Indonesia, No 64 tahun 2010., Mitigasi Bencana di Wilayah Pesisir dan Pulau-Pulau Kecil.

Peraturan Pemerintah Republik Indonesia, Nomor 21 tahun 2008., Penyelenggaraan Penanggulangan Bencana.

Peraturan Presiden Republik Indonesia, Nomor 8 tahun 2008., Badan Nasional Penanggulangan Bencana.

Puturuhu, F. 2017. Penyamaan Persepsi tentang Kerentanan dan Risiko Iklim. Workshop APIK Provinsi Maluku.

Tondobala, L. (2011). Pemahaman Tentang Kawasan Rawan Bencana dan Tinjauan Terhadap Kebijakan dan Peraturan Terkait. Jurnal Sabua. 3 (1): 58-63.

Triyono., 2015. Pengelolaan Wilayah Pesisir dan Pulau-Pulau Kecil Berbasis Risiko Bencana. http://indomarine.webs.com . Akses 13 Oktober 2017.

[UN] United Nation. (2015). Sendai Framework for Disaster Risk Reduction 2015 - 2030.

Undang - Undang Republik Indonesia Nomor 24 tahun 2007., Penanggulangan Bencana.

Undang - Undang Republik Indonesia Nomor 27 tahun 2007., Pengelolaan Wilayah Pesisir dan PulauPulau Kecil (PWP3K).

UNESCO \& UNICEF. (2012). Disaster Risk Reduction in School Curricula: Case Studies from Thirty Countries. Geneva: United Nations Children Fund and Paris: United Nations Educational, Scientific and Cultural Organization.

USAID APIK. (2018). Laporan Kajian dan Kerentanan Risiko Iklim Provinsi Maluku. 